\title{
Physical and Biochemical Studies on Excess Weight-Induced Rats Maintained on Mixed Spices-Supplemented Diet
}

\author{
*A.S. Idoko, A.S. Zaharaddeen, L.E. Ilouno, M. Ibrahim, A.M. Arinola, T.A. Dabai and G.E. Okereke \\ Department of Biochemistry, Federal University Dutsinma, Katsina state, Nigeria \\ [Corresponding Author: E-mail: asidoko1@gmail.com; $\mathbf{E}+2348060682678]$
}

\begin{abstract}
The research was conducted to assess some growth and biochemical changes in excess weightinduced male Wistar rats maintained on mixed spices-supplemented salty diet. The spices (onions, garlic, ginger and cloves) were separately pulverized and thereafter mixed in ratio of 1:2:2:2 respectively. Eight (8) Wistar rats $(151.01 \pm 1.12 \mathrm{~g})$ were randomly divided into two groups $(A$ and $B)$ of four (4) rats each with nearly equal average weight. Three experimental diets, $A, B$ and $B^{*}$ were formulated. Diet $A$ was $100 \%$ starter's mash (control diet) while Diet $B$ was $6 \%$ salt of starter's mash and $B^{*}$ was $2 \%$ mixed spices of diet $B$. The rats in groups $A$ and $B$ were maintained on their experimental diets (Diet A and Diet B respectively) ad libitum for four weeks. Diet B was then removed and replaced with diet $\mathrm{B}^{*}$ and maintained on this diet ad libitum and the feeding trial continued for another three weeks. Growth, hematological and lipid profiles, and transaminase enzyme activities in the rats were determined. There was no significant variation $(p>0.05)$ in the feed intake between the group maintained on $6 \%$ salty diet $(76.40 \pm 3.20 \mathrm{~g})$ and the control $(82.93 \pm 4.24 \mathrm{~g})$. Feed conversion ratio $(5.69 \pm 1.13)$ was significantly lower while the average weekly weight gain $(15.92 \pm 2.39 \mathrm{~g})$ was significantly higher in the group maintained on $6 \%$ salty diet when compared with the group on control diet. Supplementation of diet $B$ with $2 \%$ mixed spices (Diet $\left.B^{*}\right)$ caused significant $(p<0.05)$ decrease in weight gain $(6.19 \pm 2.01 \mathrm{~g}$ ) and increase in feed conversion ratio $(15.99 \pm 4.23)$ in excess-weight induced rats. Excess-weight induced rats (Group B) maintained on $2 \%$ mixed spices of diet $B$ had significantly $(P<0.05)$ higher PCV (41.33) and $\mathrm{Hb}$ (13.77), but there was no significant $(P>0.05)$ change in RBC (3.10), WBC (3.43) and Platelet (468.67) when compared with the control. Total cholesterol, low density lipoprotein, high density lipoprotein, and triglyceride were not significantly affected. The concentration of ALT was significantly $(p<0.05)$ higher in serum $(36.67 \pm 1.45 \mathrm{U} / \mathrm{L})$ and liver $(45.00 \pm 2.65 \mathrm{U} / \mathrm{L})$, but lower in heart $(24.67 \pm 1.76$ $\mathrm{U} / \mathrm{L}$ ) and kidney $(8.67 \pm 0.33 \mathrm{U} / \mathrm{L})$ of excess-weight induced rats (Group B) maintained on $2 \%$ mixed spices of diet B. AST however, increased $(p<0.05)$ in kidney $(24.67 \pm 1.764 \mathrm{U} / \mathrm{L})$. Therefore, $2 \%$ supplementation of metabolic disease-causing diets with mixed spices (onions, garlic, ginger and cloves) may have positive effects on reversal of excess weight gain, lipid metabolism, blood formation and organ protection in subjects fed on the diets.
\end{abstract}

Keywords: Mixed-spices; Excess weight-induced; Biochemical; Hematology; Transaminase; Lipid.

\section{INTRODUCTION}

Overweight, which is excessive fat accumulation is a risk factor for so many noncommunicable diseases such as cardiovascular diseases, diabetes mellitus and chronic respiratory diseases (WHO, 2011) and a major cause of premature death (Carmienke et al., 2013). The reported increasing cases of overweight has been attributed to increase in consumption of more energy-dense, nutrient poor foods containing high levels of sugar and saturated fats, combined with reduced physical activity (WHO, 2003). Consumption of these types of food could lead to increased oxidative stress which is thought to be the unifying factor in the progression of overweight related diseases (Delbosc et al., 2005; Bloch-Damti and Bashan, 2005).

Numerous studies have confirmed the strong association between phytochemicals, antioxidant and fibre containing foods, and health (Khalesi et al., 2015; Medina-Remón et al., 2015). Spices such as ginger, clove, onion and garlic have been reported to contain antioxidants that are effective in scavenging free radicals. Lawal et al. (2015) reported syrup produced from the combination of onions, 
garlic, tomatoes, ginger, water melon seeds, lemon and palm oil to have promising effect in the management of some of the traits of metabolic syndrome. This research was conducted to scientifically verify if supplementation of metabolic disease-causing diets with mixed spices (onions, garlic, ginger and cloves) could have effects on weight gain, lipid metabolism, blood formation and organ protection in subjects fed on the diets.

\section{Materials and Methods}

Pelletized starter's mash, product of Vital Feed, Jos, Nigeria was purchased from dealers in Dutsin-Ma Local Government. Fresh spices; ginger (Zingiber officinale), garlic (Allium sativum), onions (Allium cepa), clove (Syzygium aromaticum) were bought from Dutsin-Ma central market, Katsina state.

\section{Experimental animals}

Eight (8) male Wistar rats weighing were purchased from National Veterinary Research Institute, Vom, Plateau State. The rats were housed in standard wooden cages and allowed to acclimatize for one week before the commencement of the experiment.

\section{Preparations of spices}

Fresh bulbs of onions, garlic, ginger and cloves were carefully screened to remove spoilt ones. The spices (onions, garlic, ginger and cloves) were separately pulverized and thereafter mixed in ratio of 1:2:2:2 respectively. This was followed by thorough mixing to achieve homogeneity.

\section{Formulation of experimental diet}

The starter's mash (Vital feed, Jos) was mixed to form three experimental diets for two groups as follows:

Diet A: Diet based on 100\% starter's mash (control diet)

Diet B: Diet based on $6 \%$ salt of starter's mash.

Diet $B^{*}$ : Diet based on $2 \%$ mixed spices of diet B.

These contents were mixed thoroughly to achieve homogeneity, pelleted and air dried for six (6) hours after which they were packaged for use.

\section{Experimental Design}

The experiment was conducted in two stages;

\section{Stage one \\ Induction of excess weight}

The eight rats were divided into groups $A$ and $B$ with average weight of $151.01 \pm 1.12 \mathrm{~g}$. Each group contained four rats. Group A was given the control diet while Group B was given diet based on $6 \%$ salt of starter's mash (B) to induce excess weight. The rats were maintained on their respective diets and water ad libitum for four weeks.

\section{Stage two \\ Determination of the effect of mixed spices in management of excess weight gain}

Group $A$ in stage one remained on diet $A$ (control). In Group B (excess weight induced group), diet B (Diet based on $6 \%$ salt of starter's mash) was replaced with diet $B^{*}(2 \%$ mixed spices of $\operatorname{diet} B$ ) and the feeding trial continued for another three weeks.

Determination of feed intake: To determine feed intake, the quantity of feed left over was subtracted from the quantity of feed served within 24- hour interval.

Feed conversion ratio: The weekly feed conversion ratio was calculated by dividing the mean of the feed consumed per week by the difference in weight per week.

Determination of body weight change: The rats were weighed at the commencement of the experiment using digital scale and thereafter on weekly basis to determine change in weight.

Animal sacrifice, collection of blood samples and preparation of tissue homogenate. After 49 days of feeding trial, the animals were weighed and sacrificed by anaesthetizing them in a jar containing cotton wool soaked in diethylether. Blood was obtained through the jugular veins in tubes containing EDTA as anticoagulant and in plain tubes. Serum was separated from the blood in plain 
tubes by allowing the blood to clot for 3 hours. The clotted blood was spun in a bench top centrifuge at $1500 \mathrm{rpm}$ for 15 minutes to obtain serum. The serum samples were thereafter separated into another set of plain sample tubes and kept in the refrigerator (Akanji and Ngaha, 1989). The sacrificed rats were dissected to remove the tissues of interest: liver, heart and kidney. The isolated tissues were weighed and a portion cut out, cut into very small pieces and then homogenized in icecold $0.25 \mathrm{M}$ sucrose solution (Akanji and Yakubu, 2000).

Determination of Haematological: Haematological parameters such haemoglobin $(\mathrm{Hb})$, Packed cell volume (PCV), red blood cells (RBC), mean corpuscular volume (MCV), mean corpuscular haemoglobin $(\mathrm{MCH})$, mean corpuscular haemoglobin concentration (MCHC), white blood cells(WBC) and platelet were estimated using an automated haematology analyser, SYSMEX KX21JAPAN.

Determination of biochemical parameters: Lipid profiles and transaminases (ALT and AST) activities were determined using commercially available Randox biochemical kits from Randox Laboratories Limited.

\section{Statistical Analysis}

Results were expressed as means \pm SEM. Using statistical package program (SPSS 16.0 version), Student t-test was used to assess statistical significance where $p<0.05$ was considered significant.

\section{RESULTS}

Feed consumption in rats maintained on $6 \%$ salty diet and in rats maintained on the control did not differ significantly $(p>0.05)$. Compared to the control however, rats fed on $6 \%$ salty diet had significantly $(P<0.05)$ lower feed conversion ratio but higher weight gain (Table 1).

Supplementation of $6 \%$ salty diet with mixed spices (diet $B^{*}$ ) did not significantly $(p>0.05)$ change the food consumption pattern of excess weight- induced rats (Group B), but significantly $(P<0.05)$ increased the feed conversion ratio and lowered the average weekly weight gain (Table 2).

Table 1: Feed consumption, feed conversion ratio and change in weight in rats fed on $6 \%$ salty diet (Induction of excess weight)

\begin{tabular}{|c|c|c|}
\hline Parameters & Group A & Group B \\
\hline Feed consumed (g) & $76.40 \pm 3.20^{a}$ & $82.93 \pm 4.24^{a}$ \\
\hline Feed conversion ratio & $14.10 \pm 6.76^{a}$ & $5.69 \pm 1.13^{b}$ \\
\hline Weight gained (g) & $8.63 \pm 7.37^{a}$ & $15.92 \pm 2.39 \mathrm{~b}$ \\
\hline \multicolumn{3}{|c|}{$\begin{array}{l}\text { Results are means of } 3 \text { determinations per group } \pm \text { SEM } \\
\text {.Values along the row with the same superscript are not } \\
\text { significantly different ( } p>0.05) ; \\
\text { Group A: Rats maintained on } 100 \% \text { starters mash (control).; } \\
\text { Group B: Rats maintained on starter's mash containing } 6 \% \text { salt }\end{array}$} \\
\hline
\end{tabular}

Table 2: Feed consumption, feed conversion ratio and weight change in excess weightinduced rats fed on mixed spices-supplemented salty diet

\begin{tabular}{lll}
\hline Parameters & $\mathrm{B}$ & $\mathrm{B}^{*}$ \\
Feed consumed $(\mathrm{g})$ & $79.34 \pm 3.20^{\mathrm{a}}$ & $82.07 \pm 3.09^{\mathrm{a}}$ \\
Feed conversion ratio & $4.57 \pm 0.35^{\mathrm{a}}$ & $15.99 \pm 4.23^{\mathrm{b}}$ \\
Weight gained $(\mathrm{g})$ & $18.09 \pm 1.42^{\mathrm{a}}$ & $6.19 \pm 2.01^{\mathrm{b}}$ \\
\hline
\end{tabular}

Results are means of 3 determinations per group \pm SEM .Values along the row with the same superscript are not significantly different $(P>0.05)$, and are significantly different if the superscripts are different.

Group B: Rats maintained on diet based on $6 \%$ salt of starter's mash (diet B) and water.

Group $B^{*}$ : After four weeks of feeding on diet $B$ by rats in Group B, diet $B$ was replaced by diet based on $2 \%$ mixed spices of diet $B$ and water

The plasma concentrations of platelet, MCV, $\mathrm{MCH}, \mathrm{MCHC}, \mathrm{WBC}$ and RBC in excess weightinduced rats fed on mixed spices supplemented-salty diet (diet $\left.B^{*}\right)$ were not significantly different $(P>0.05)$ when compared to rats maintained on the control diet.

The result showed significant increase in PCV and $\mathrm{HB}$ in excess weight-induced rats fed on mixed spices supplemented-salty diet (Table 3). Compared to the control, rats fed on $2 \%$ mixed spices supplemented-salty diet showed no significant $(P<0.05)$ difference in lipid profile (Table 4). 
Table 3: Hematological profiles of excess weight-induced rats fed mixed spicessupplemented salty diet

\begin{tabular}{lll}
\hline Parameters & Group A & Group B \\
\hline Platelet $\left(1 \times 10^{\circ} /\right)$ & $481.33 \pm 8.67^{\mathrm{a}}$ & $468.67 \pm 6.74^{\mathrm{a}}$ \\
PCV $(\%)$ & $33.67 \pm 0.67^{\mathrm{a}}$ & $41.33 \pm 2.03^{\mathrm{b}}$ \\
HB $(\mathrm{g} / \mathrm{dl})$ & $11.23 \pm 0.23^{\mathrm{a}}$ & $13.77 \pm 0.69^{\mathrm{b}}$ \\
WBC $\left(1 \times 10^{9} / \mathrm{l}\right)$ & $3.53 \pm 0.09^{\mathrm{a}}$ & $3.43 \pm 0.15^{\mathrm{a}}$ \\
RBC $\left(1 \times 10^{9} /\right)$ & $3.30 \pm 0.12^{\mathrm{a}}$ & $3.10 \pm 0.21^{\mathrm{a}}$ \\
MCV (fl) & $111.67 \pm 5.67^{\mathrm{a}}$ & $133.33 \pm 6.36^{\mathrm{a}}$ \\
MCH $(\mathrm{pg})$ & $37.27 \pm 1.87^{\mathrm{a}}$ & $44.57 \pm 2.18^{\mathrm{a}}$ \\
MCHC $(\mathrm{g} / \mathrm{dl})$ & $33.27 \pm 0.03^{\mathrm{a}}$ & $33.27 \pm 0.09^{\mathrm{a}}$ \\
\hline
\end{tabular}

Results are means of 3 determinations per group \pm SEM Values along the row with the same superscript are not significantly different $(P>0.05)$, and are significantly different if the superscripts are different.

Group A: Rats maintained on $100 \%$ starters mash (control)

Group $B^{*}$ : After four weeks of feeding on diet $B$ by rats in Group $B$, diet $B$ was replaced by diet based on $2 \%$ mixed spices of diet $B$ and water

RBC: red blood cells; HB: haemoglobin; PCV: Packed cell volume; MCV: mean corpuscular volume; $\mathrm{MCH}$ : mean corpuscular haemoglobin; MCHC: mean corpuscular haemoglobin concentration; WBC: white blood cells

Table 4: Lipid parameters of excess weightinduced rats fed mixed spices-supplemented salty diet

\begin{tabular}{lll}
\hline Parameters & Group A & Group B \\
Total & $2.6 \pm 0.00^{\mathrm{a}}$ & $2.63 \pm 0.33^{\mathrm{a}}$ \\
cholesterol(mmol/l) & $1.00 \pm 0.00^{\mathrm{a}}$ & $1.01 \pm 0.58^{\mathrm{a}}$ \\
Triglyceride $(\mathrm{mmol} / \mathrm{l})$ & & \\
$\mathrm{HDL}-\mathrm{C}(\mathrm{mmol} / \mathrm{l})$ & $0.73 \pm 0.03^{\mathrm{a}}$ & $0.60 \pm 0.58^{\mathrm{a}}$ \\
$\mathrm{LDL}-\mathrm{C}(\mathrm{mmol} / \mathrm{l})$ & $1.48 \pm 0.33^{\mathrm{a}}$ & $1.50 \pm 0.23^{\mathrm{a}}$ \\
\hline
\end{tabular}

Results are means of 3 determinations per group \pm SEM Values along the row with the same superscript are not significantly different $(P>0.05)$, and are significantly different if the superscripts are different.

Group A: Rats maintained on 100\% starters mashsh (control)

Group $B^{*}$ : After four weeks of feeding on $\operatorname{diet} B$ by rats in Group B, diet B was replaced by diet based on $2 \%$ and water

The concentrations of serum and liver ALT were significantly $(p<0.05)$ higher in the excess weight-induced group maintained on $2 \%$ mixed spices-supplemented diet (Diet $\mathrm{B}^{*}$ ) as compared to the Control group while the concentrations in the kidney and heart were significantly $(p<0.05)$ lower (Table 5$)$. The concentration of kidney AST was significantly $(p$
$<0.05)$ increased in the excess weight-induced group maintained on $2 \%$ mixed spicessupplemented diet as compared to the Control group. The concentrations in serum, liver and heart did not vary significantly $(p>0.05)$ (Table $6)$.

Table 5: ALT concentration(U/L) levels in excess weight-induced rats maintained on mixed spices supplemented diet

\begin{tabular}{lll}
\hline Organ & Group A & Group B* \\
Serum & $34.33 \pm 5.48^{\mathrm{a}}$ & $36.67 \pm 1.45^{\mathrm{b}}$ \\
Liver & $42.33 \pm 0.88^{\mathrm{a}}$ & $45.00 \pm 2.65^{\mathrm{b}}$ \\
Kidney & $13.33 \pm 2.91^{\mathrm{a}}$ & $8.67 \pm 0.33^{\mathrm{b}}$ \\
Heart & $28.00 \pm 1.53^{\mathrm{a}}$ & $24.67 \pm 1.76^{\mathrm{b}}$
\end{tabular}

Results are means of 3 determinations per group \pm SEM Values along the row with the same superscript are not significantly different $(P>0.05)$, and are significantly different if the superscripts are different.

Group A: Rats maintained on diet based on $100 \%$ starters mash (control) and water.

Group B*: After four weeks of feeding on diet B by rats in Group B, diet B was replaced by diet based on $2 \%$ mixed spices of diet $B$ and water

Table 6: AST concentration (U/L) levels in excess weight-induced rats maintained on mixed spices supplemented diet

\begin{tabular}{lll}
\hline Organ & Group A & Group $B^{*}$ \\
Serum & $10.67 \pm 0.33^{a}$ & $10.33 \pm 0.67^{a}$ \\
Liver & $12.00 \pm 1.00^{a}$ & $11.93 \pm 0.67^{a}$ \\
Kidney & $21.33 \pm 0.33^{a}$ & $24.67 \pm 1.764^{b}$ \\
Heart & $14.00 \pm 0.57^{a}$ & $14.67 \pm 0.33^{a}$ \\
\hline
\end{tabular}

Results are means of 3 determinations per group \pm SEM .Values along the row with the same superscript are not significantly different $(P>0.05)$, and are significantly different if the superscripts are different.

Group A: Rats maintained on $100 \%$ starters mash (control)

Group $B^{*}$ : After four weeks of feeding on diet $B$ by rats in Group B, diet B was replaced by diet based on $2 \%$

\section{DISCUSSION}

Feed consumption, feed conversion ratio and change in weight in rats fed on salty diet.

Although addition of salt has been reported to increase the palatability of many foods and encourage greater energy intake (Bolhuis et al., 2012) by disrupting the satiety signal, the 
insignificant increase in the food consumed by the rats on $6 \%$ salty diet could be due to high concentration of the salt. Key contents and physical properties of foods such as flavour, texture and taste affect satiety (Farran et al., 2005). The significantly lower feed conversion rate in rats maintained on $6 \%$ salty diet indicates that $6 \%$ salty diet may cause a greater increase in weight as compared to the control. This is evidenced in the observed remarkably significant increase in weight of rats maintained on salty diets. Since feed consumption was not significantly different between the groups, the increase in weight could be attributed to the salt contents. This finding is in agreement with some studies that reported an association between sodium intake and adiposity measures, which are independent of energy intake (Yi et al., 2015; Yoon, 2013; Larsen et al., 2013). Although, the mechanism which may explain this relationship is not quite clear, findings from animal studies indicate that a diet high in sodium increases adipose tissue mass, and this is due to changes in insulin and glucose metabolism which favour fat accumulation (Fonseca et al., 2007; Takada et al., 2008). According to Mi-Kyung (2016), high sodium intake increases adiponectin level through the activation of adipose PPARס, and the enhanced adiponectin downregulates renal SGLT2. Therefore, long term consumption of salty diet could lead to obesity and metabolic syndromes such as diabetes.

\section{Feed consumption rate, feed conversion ratio and change in weight in excess weight- induced rats fed on mixed spices supplemented-salty diet}

The no effect of mixed spices supplementation on feed consumption indicates that the overall physical properties and key contents of the salty diet may not have been affected by supplementation with mixed spices. These properties such as palatability play significant roles in satiety and food consumption. Helene et al. (2010) reported that adding spices to the meals had only minor effects on total energy intake $(\mathrm{kJ})$ and no effect on total food intake $(\mathrm{g})$, water intake, hunger and satiety. The reduction in the weight of rats maintained on $2 \%$ mixed spices of salty diet (Diet $B^{*}$ ) could have been due to the pungent compounds in spices which have been reported to increase rate of metabolism and course loss of weight (Jungbauer and Medjakovic, 2012). Aqueous extracts of clove (Broadhurst et al., 2000) and ginger (Asdaq and Inamdar, 2011) have insulinlike biological activity and positive effect on weight reduction. Similarly, Kang et al. (2010) reported that 8 weeks' intake of an onion drink containing quercetin had anti-obesity effects in obese rats. It is evident from the finding in this work that these spices (onion, ginger, clove and garlic) could act synergistically to improve metabolic rate and decrease accumulation of excess weight.

\section{Biochemical changes in excess weight- induced rats fed mixed spices- supplemented salty diet}

Blood cells regulation to prevent excessive variation in their quality and quantity, according to (Guyton and Hall, 2004) is achieved via some specialized feedback mechanisms for the cells. The increase in packed cell volume (PCV) and haemoglobin concentrations in rats maintained on mixed spices supplemented salty diet suggests that bioactive contents of these spices such as alliin, allcin, eugenol could stimulate the erythropoetic synthesis of haemoglobin and increase the percentage red blood cells.

This is partly consistent with the finding by Enitan et al. (2012), who reported that PCV and haemoglobin were significantly increased in a dose-dependent manner in both onion and garlic treated groups when compared to the control.

The results of the lipid profiles are quite interesting since the problems of poor dieting and chunk foods bothers on lipid peroxidation and its concomitant effects (Muoio and Newgard, 2008). Lipid elevations, even if moderate, can result in severe risks. The insignificant difference could have been due to the ameliorating effects of the spices on the lipid parameters. Onion and garlic contain pungent sulfur compounds which according to 
Lanzotti (2006) hinder among other things obesity and hypercholesterol. Ashraf et al. (2011) similarly reported that garlic reduces Total cholesterol and LDL cholesterol while increasing HDL to a greater amount in patients compared to the control. This may explain why garlic slows atherosclerotic plaque formation as reported by Budoff (2006). Ginger also has positive effect on lipid which include promoting cholesterol transformation into bile salts, promoting biliary excretion of excess cholesterol, improving blood viscosity by reducing platelet aggregation, and reducing inflammatory and oxidative damage to vascular endothelium by reducing thromboxane synthesis and favoring series 2 prostaglandins (Jillian, 2017). The mechanism for these effects is not very clear but allicin, an organosulfur compound found in some spices had been reported to inhibit HMG-CoA reductase in both rat hepatocytes and HepG2 cells (Gebhardt and Beck, 1996). The finding in this study indicates that dyslipideamia which is always associated with poor dieting could be managed by supplementing the diets with spices mixed as shown.

Transaminases (ALT and AST) are predominantly found in the liver but are also localized within the cells of the kidney, heart, muscle and other organs. The significant increase in serum concentration of ALT in rats maintained on mixed spices supplemented salty diet could have been due to damage done to the kidney and heart since there was corresponding decrease in the activity of the enzyme in these organs. This indicates that salty diet and the consequent excess weight may have more deleterious effect on the kidney and heart rather than the liver. It is also probable that the inclusion of mixed spices restored the integrity of the liver from any damage that the salty diet might have caused. The inclusion of the mixed spices may have elicited increased synthesis of AST on the kidney as could be seen in the increased activities of AST in the kidney. The non leakage of this enzyme into the serum as was the case for ALT is not clear. It could however be due to ameliorating effect of the spices on the lipid bi- layer of the organs. A serious limitation of this study is the fact that the damage/change caused by the salty diet on the studied parameters was not measured before supplementation with mixed spices. However, a large body of studies had established association of high salty diet with poor blood formation, dyslipideamia and cytolysis (Ogihara et al., 2002; Jian-Wei et al., 2008; Lawal et al,. 2015).

\section{CONCLUSION}

It is our conclusion from the findings in this research that $2 \%$ supplementation of metabolic disease-causing diets with mixed spices (onions, garlic, ginger and cloves) has potential to decrease the average weekly weight gain, lipid metabolism, blood formation and organ protection in over-subjects fed on the diets.

\section{REFERENCES}

Abaje, I.B., Ogoh, A.O., Amos, B.B., Abashiya, M. (2015). Climate Change, Flood Disaster Assessment and Human Security in Katsina State, Nigeria American Journal of Human Ecology, 4(4):47-56.

Abell, L.L., Levey, B.B., Brodie, B.B. (1952). Determination of cholesterol in serum and plasma. Journal of Biological Chemistry, 195:357

Akanji, M. A. and Ngaha, E. O. (1989). Effect of repeated administration of berenil on urinary excretion with corresponding tissue pattern in rats. Pharmacology and Toxicology, 64: 272-275.

Akanji, M. A. and Yakubu, M.T. (2000). aTocopherol protects against metabiosulphate-induced tissue damage in rats. Nigirian Journal of Biochemistry and Molecular Biology, 15(2): 179-183.

Asdaq, S. M. B., Inamdar, M. N. (2011). Pharmacodynamic and pharmacokinetic interactions of propranolol with garlic (Allium sativum) in rats. Evidence-based Complementary and Alternative Medicine, 2011(2011): 24042. 
Ashraf, R.1., Khan, R.A., Ashraf, I. (2011). Garlic (Allium sativum) supplementation with standard antidiabetic agent provides better diabetic control in type 2 diabetes patients. Pakistan Journal of Pharmaceutical Sciences, 24(4):56570.

Bloch-Damti, A. and Bashan, N. (2005). Proposed mechanisms for the induction of insulin resistance by oxidative stress. Antioxidants and Redox Signaling, 7(11): 1553-1567.

Budoff, M.1. (2006). Aged garlic extract retards progression of coronary artery calcification. The Journal of Nutrition, 136(3):741-744.

Bolhuis, D.P. Lakemond, C.M., de Wijk, R.A., Luning, P.A., de Graaf, C.(2012). Effect of salt intensity in soup on ad libitum intake and on subsequent food choice. Appetite, 58(1):48-55.

Broadhurst, C. L., Polansky, M. M., Anderson, R. A. (2000). Insulin like biological activity of culinary and medicinal plant aqueous extracts in-vitro. Journal of Agricultural and Food Chemistry, 48(3): 849-852.

Carmienke, S., Freitag, M.H., Pischon, T. (2013). General and abdominal obesity parameters and their combination in relation to mortality: a systematic review and meta-regression analysis. European Journal of Clinical Nutrition, 67(6):573-585.

Delbosc, S., Paizanis, E., Magous, R. (2005). Involvement of oxidative stress and NADPH oxidase activation in the development of cardiovascular complications in a model of insulin resistance, the fructose-fed rat. Atherosclerosis, 79:43-9.

Enitan, S. S., Ajeigbe, K. O., Josiah, S. J., Ehiaghe, F. A., Bielu, M. C. (2012). Haematological and Hepatoprotective Effects of Allium Cepa and Allium sativum Extracts in Rats. European Journal of Medicinal Plants, 2(4): 290307.
Fonseca-Alaniz, M.H., Brito, L.C, Borges-Silva, C.N, Takada, J., Andreotti, S., Lima, F.B. (2007).High dietary sodium intake increases white adipose tissue mass and plasma leptin in rats. Obesity (Silver Spring), 15(9):2200-2208.

Gebhardt, R., Beck, H. (1996). Differential inhibitory effects of garlic-derived organosulfur compounds on cholesterol biosynthesis in primary rat hepatocyte cultures. Lipids, 31:1269-76.

Farran, M.T., Halaby, W.S., Barbour, G.W., Uwayjan, M.G., Sleiman, F.T. and Ashkarian, V.M. (2005). Effects of feeding ervil (Vicia ervilia) seeds soaked in water or acetic acid on performance and internal organ size of broilers and production and egg quality of laying hens. Poultry Science, 84(11): 1723-1728.

Friedewald, W.T., Levy, R.I. and Fredrickson, D.S. (1972). Estimation of low-density lipoprotein cholesterol without the use of the preparative ultracentrifuge. Clinical Chemistry, 18(6): 499-502.

Guyton, A.C. and Hall, J.E. (2004). Textbook of Medical Physiology. 11, Ed., W.B. Saunders Publishers, Philadelphia.

Helene, C.R., Torben, M., Per, M. (2010). Effects of hot spices on energy intake, appetite and sensory specific desires in humans. Food Quality and Preference, 21: 655-661.

Jian-Wei, G., Amelia, P. B., Wei, T., Megan, S., Emily, Y. (2008). Long-term High Salt Diet Causes Hypertension and Decreases Renal Expression of Vascular Endothelial Growth Factor in Sprague-Dawley Rats. Journal of the American Society of Hypertension, 2(4): 275-285.

Jillian, S. (2017). BOTANICAL INFLUENCES ON METABOLIC SYNDROME. Retrieved

April $\quad 10, \quad 2017$ from https://www.americanherbalistsguild.co $\mathrm{m} / \mathrm{sites} /$ default/files/botanicalinfluences onmetabolicsyndrome0.pdf

Jungbauer, A., Medjakovic, S. (2012). Antiinflammatory properties of culinary 
herbs and spices that ameliorate the effects of metabolic syndrome. Maturitas, 71(3): 227-239.

Kang, W.Y., Kim, M.Y., Jin, J.Y., Yang, H.K., Hong, H.J., Kim, D.K., Han, C.H., Lee, Y.J. (2010). Anti-obesity effects of onion juice in high fat diet-induced obese rats. Korean Journal of Veterinary Research, 50:1-10.

Khalesi S, Irwin C, Schubert M. (2015). Flaxseed consumption may reduce blood pressure: a systematic review and meta-analysis of controlled trials. The Journal of Nutrition, 145:758-765.

Lawal, N., Idoko, A. S., Sullubawa, A.S. (2015). Serum glucose, lipid profile and oxidative stress markers of salt-induced metabolic syndrome rats administered antioxidant rich nutraceutical. International Journal of Biochemistry Research \& Review, 10(3): 1-7.

Larsen, S.C., Angquist, L., Sorensen, T.I., Heitmann, B.L. (2013). 24h urinary sodium excretion and subsequent change in weight, waist circumference and body composition. Public Library of Science One, 8(7): e69689.

Lanzotti, V. (2006). The analysis of onion and garlic. Journal of Chromatography $A$, 1112: 3-22.

Medina-Remón A, Tresserra-Rimbau A, Pons A. (2015). Effects of total dietary polyphenols on plasma nitric oxide and blood pressure in a high cardiovascular risk cohort. The PREDIMED randomized trial. Nutrition, Metabolism and Cardiovascul ar Diseases, 25:60-7.

Mi-Kyung, K. (2016). Dietary Sodium Intake in Patients with Type 2 Diabetes Mellitus. Diabetes and Metabolism Journal, 40(4): 280-282.

Muoio, D.M., Newgard, C.B. (2008). Mechanisms of disease: Molecular and metabolic mechanisms of insulin resistance and $\beta$-cell failure in type 2 diabetes. Nature Reviews Molecular Cell Biology, 9: 193-205.

Ogihara, T., Asano, T., Ando, K. (2002). Highsalt diet enhances insulin signaling and induces insulin resistance in Dahl salt sensitive rats. Hypertension; 40: 8389.

Organização Mundial de Saúde. Global status report on noncommunicable diseases. (2011).Geneva: WHO. Retrieved 15 March,

2018 www.who.int/nmh/publications/ncd_rep ort_full_en.pdf

Takada, J., Fonseca-Alaniz, M.H. Andreotti, S., de Campos, T.B., Campana, A.B., Borges-Silva, C.N. (2008). High sodium intake enhances insulinstimulated glucose uptake in rat epididymal adipose tissue. Obesity (Silver Spring), 16(6):1186-1192.

Tietz, N.W. (1990). Clinical Guide to Laboratory Tests (2nd ed.). Philadelphia, USA W.B. Sauders Company.

WHO. (2003). Obesity and Overweight. Retreived April 11, 2018 from www.who.int/dietphysicalactivity/media/ en/gsfs_obesity.pdf

Yi, S.S., Firestone, M.J., Beasley, J.M. (2015). Independent associations of sodium intake with measures of body size and predictive body fatness. Obesity (Silver Spring), 23(1):20-3.

Yoon, Y.S., Oh, S.W. (2013). Sodium density and obesity; the Korea National Health and Nutrition Examination Survey 2007-2010. European Journal of Clinical Nutrition, 67(2):1416. 